\title{
A NATURAL HYBRID IN THE GENUS CLIVIA
}

The genus Clivia, with six described species, is The group is of considerable horticultural significance endemic to South Africa and Swaziland (Duncan 1999; and its members, including many cultivars, are extenRourke 2002; Swanevelder 2003; Murray et al. 2004). sively grown all over the world (Swanevelder 2003). 
Artificial hybridization between the different species of Clivia results in attractive progeny, currently highly sought after in cultivation (Koopowitz 2002; Swanevelder 2003). Numerous references to such hybrids between $C$. miniata (Lindl.) Regel and C. nobilis Lindl.; C. miniata and $C$. gardenii Hook.; and $C$. miniata and $C$. caulescens R.A.Dyer have been recorded in the literature (Koopowitz 2002; Rourke 2003; Swanevelder 2003). Natural interspecific hybridization in the genus has, however, rarely been documented. Rourke (2003) reported a natural hybrid between $C$. miniata and $C$. caulescens from the Bearded Man Mountain near Barberton, Mpumalanga, and its subsequent cultivation at Kirstenbosch National Botanical Garden. Swanevelder (2003) reviewed both the natural and artificial hybrids known in the genus.

The recognition of hybrids in nature is sometimes regarded as somewhat speculative and the existence of such entities is usually based on circumstantial evidence. Generally, the possession of intermediate morphological features, proximity to the putative parents, hybrid fertility with segregation recognizable in the $F_{2}$ progeny, preferably supplemented by the artificial hybridization of the putative parents, are applied as criteria in support of a natural hybrid (Stewart \& Manning 1982).

Hitherto, no natural hybrids (nothotaxa) have been formally described in Clivia - despite the existence of numerous records indicating that at least two species grow sympatrically in different localized populations (over the full distribution range of the genus). Here, for the first time, we formally describe a natural hybrid in Clivia. The identity of the hybrid is supported by the four criteria stipulated above (Stewart \& Manning 1982). The new nothospecies is intended to cover all hybrids between $C$. miniata (both var. miniata and var. citrina) and $C$. caulescens.

Clivia $\times$ nimbicola Z.H.Swanevelder, J.T.Truter \& A.E.van Wyk, nothosp. nov., hybrida naturalis inter Cliviam miniatam et $C$. caulescentem. Rhizoma aeria inter illos specierum parentalium intermedia. Folia arcuata, $250-350 \mathrm{~mm}$ longa, 55-70 $\mathrm{mm}$ lata, marginibus integris, apice acuta. Flores numero $10-20(-30)$; pedicellis suberecto, perianthio tubiformi, $30-60 \mathrm{~mm}$ longo, suberecto, segmentis patulis.

TYPE.-Swaziland, 2531 (Barberton): Bearded Man Mountain, (-CB), 30-05-2003, Pearton TP01 (PRU, holo.).

Rhizomatous, solitary or clumping, stout, evergreen perennial, $0.4-1.2 \mathrm{~m}$ tall. Leaf sheath green to pale red. Leaves long-lived, arching, strap-shaped, 250-350 × 55$70 \mathrm{~mm}$, apex acute; margins usually entire, rarely \pm serrated. Scape 200-600 × 10-30 mm, green. Inflorescence umbel-like, 10-20(-30)-flowered, usually loose/open and \pm flat-topped; pedicels stiff, erect to drooping, $15-40 \mathrm{~mm}$ long, green. Flowers semi-erect to drooping, Perianth tubular to trumpet-shaped, $30-60 \mathrm{~mm}$ long, segments spreading, pastel orange to pastel pink, occasionally with green apices. Stamens 6, variable in degree of exsertion at anthesis. Style 30-55 mm long; stigma trilobed, apex penicillate. Ovary ovoid, green, trilocular. Fruit 10-30 berries, green maturing to red. Seeds $1-4$, subglobose, \pm $10-15 \mathrm{~mm}$ in diam., pearly white. Figure 13 .

Clivia $\times$ nimbicola is intermediate between Clivia caulescens and Clivia miniata with regards to rhizome, leaf, umbel and flower morphology (Table 2). Flower colour ranges from pastel orange to pastel pink, with green tepal apices in some specimens. Flowering is erratic, occurring all year round, mainly from July through to December, with some specimens flowering twice yearly-February to May. This long flowering period connects the flowering periods of the two putative parents in the Bearded Man Mountain locality, namely October-November in C. miniata and October-December in C. caulescens. The extended flowering period of $C . \times$ nimbicola is regarded as further evidence in support of the taxon's hybrid origin. The formal description of C. $\times$ nimbicola is also supported by the observation that the hybrid plants bear berries in the wild, thereby inferring fertility and the possibility to maintain populations by means of subsequent breeding among hybrid plants.

Field observations suggest some introgression between Clivia $\times$ nimbicola and its putative parents. Where populations of $C$. $\times$ nimbicola occur close to or amongst $C$. caulescens, back-crossing of the hybrid with $C$. caulescens produces umbels with fewer flowers which are tubular, yet more open than in typical $C$. caulescens. Likewise, where the hybrid occurs close to or amongst $C$. miniata, the umbels are less floriferous and the flowers are more funnel-shaped, yet not as open as in typical C. miniata. It is suggested that from the inferred initial progeny cross, subsequent generations have resulted from various backcrossings, resulting in a hybrid-swarm. Artificial hybridization between $C$. miniata and $C$. caulescens is usually successful with records dating back to 1945 (e.g. 1945/66, R. Marais PRE37106). Morphologically the resultant hybrids closely match the plants of $C$. $\times$ nimbicola in the wild.

The holotype of Clivia $\times$ nimbicola was collected on the Bearded Man Mountain near Barberton (Figure 14), on the border between South Africa and Swaziland. In this area these natural hybrids are quite common (50 or more individuals) in sympatric stands of $C$. miniata and $C$. caulescens. Judging by plant sizes and the height of aerial stems, original hybrids are as old as their putative parents. Toppled plants with long aerial stems, from either parentage of hybrid, freely produce suckers when in contact with the soil. Seedlings, when present, were usually distributed around its putative parent. The natural distribution range of $C . \times$ nimbicola is confined to the Barberton Centre of Endemism (Van Wyk \& Smith 2001), the only known region in which the distribution ranges of $C$. caulescens and C. miniata overlap (Swanevelder 2003). At least three separate, well-established populations of $C$. $\times$ nimbicola were recorded, with stands extending into both Swaziland and South Africa. C. caulescens prefers steep cliff faces or steep rocky embankments, whereas C. miniata generally prefers gentler scree embankments or flatter forest habitats. The $C . \times$ nimbicola plants are distributed between and amongst both parents, occupying both specific habitats found in the Afromontane Forest. The epithet nimbicola means dweller in the mist, and 


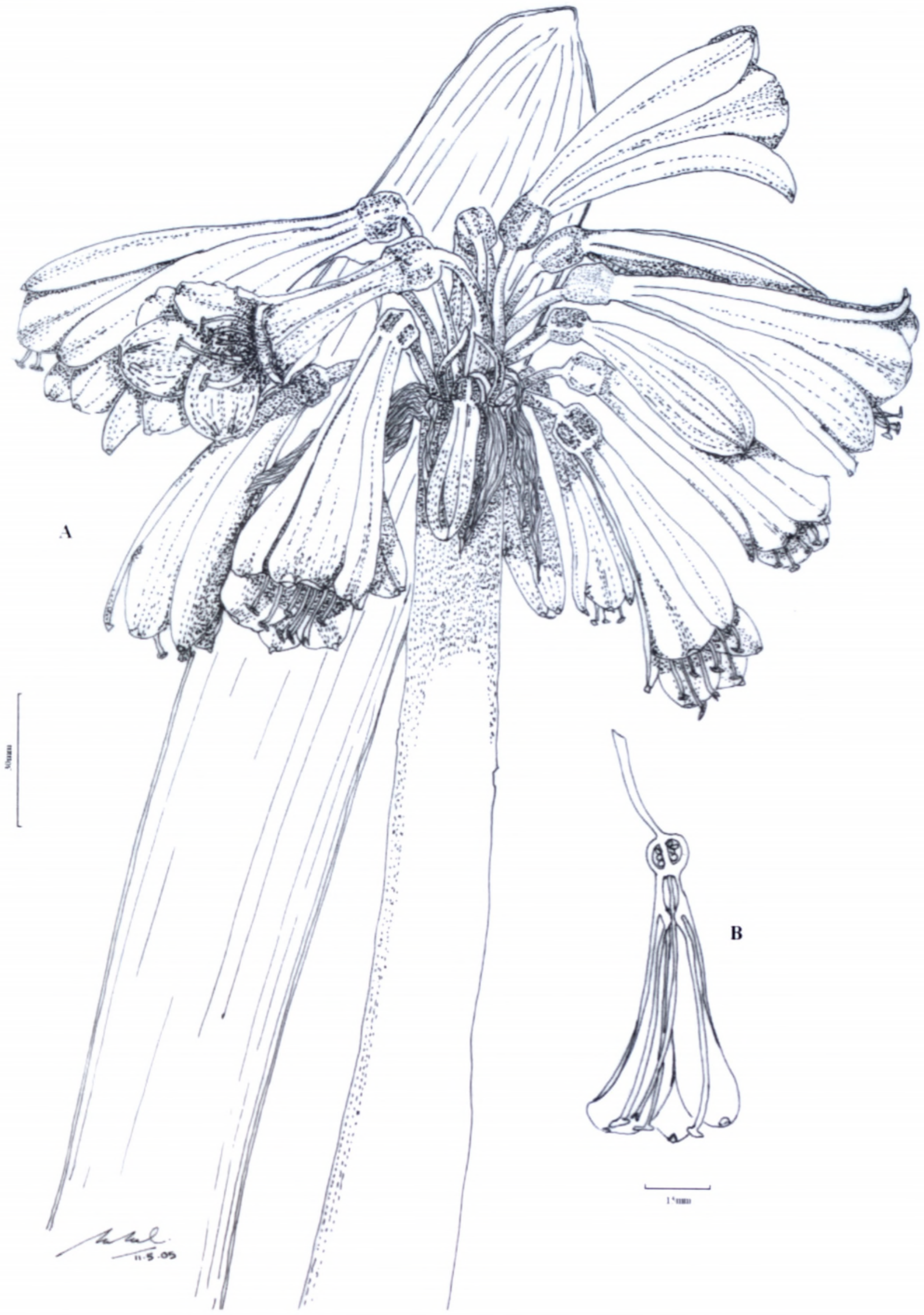


TABLE 2. - Comparison of Clivia $\times$ nimbicola with its putative parents at Bearded Man Mountain, Mpumalanga and Swaziland

\begin{tabular}{|c|c|c|c|}
\hline Character & C. caulescens & C. $\times$ nimbicola & C. miniata \\
\hline Aerial stem & $\begin{array}{l}\text { present in mature plants, length age- } \\
\text { dependant }\end{array}$ & $\begin{array}{l}\text { present in mature plants, length } \\
\text { age-dependant but shorter than in } \\
\text { C. caulescens }\end{array}$ & $\begin{array}{l}\text { present in populations when plants } \\
\text { are mature, length age-dependant, } \\
\text { usually shorter than in hybrid }\end{array}$ \\
\hline $\begin{array}{l}\text { Leaf } \\
\text { sheath colour } \\
\text { orientation } \\
\text { length } \times \text { width }(\mathrm{mm}) \\
\text { apex } \\
\text { margin }\end{array}$ & $\begin{array}{l}\text { green to pale red } \\
\text { arching } \\
300-600 \times 35-45 \\
\text { obtuse - acute } \\
\text { rarely serrated }\end{array}$ & $\begin{array}{l}\text { green to pale red } \\
\text { arching } \\
250-350 \times 55-70 \\
\text { acute } \\
\text { usually entire, occasionally serrated }\end{array}$ & $\begin{array}{l}\text { green to pale red } \\
\text { arching } \\
450-600 \times 35-70 \\
\text { acute } \\
\text { usually entire }\end{array}$ \\
\hline Umbel form & usually compact, flattened on one side & loose/open, \pm flat-topped & loose, almost globose \\
\hline $\begin{array}{l}\text { Pedicel } \\
\text { orientation } \\
\text { colour } \\
\text { length }(\mathrm{mm})\end{array}$ & $\begin{array}{l}\text { stiff, erect, drooping } \\
\text { just below flower } \\
\text { usually green } \\
15-35\end{array}$ & $\begin{array}{l}\text { stiff, erect to drooping } \\
\text { green } \\
15-40\end{array}$ & $\begin{array}{l}\text { stiff and erect } \\
\text { green } \\
30-70\end{array}$ \\
\hline $\begin{array}{l}\text { Flower } \\
\text { number } \\
\text { orientation } \\
\text { length (perianth and ovary) } \\
\text { perianth shape }\end{array}$ & $\begin{array}{l}14-40(-50) \\
\text { drooping } \\
30-45 \mathrm{~mm} \\
\text { tubular and curved; inner segments } \\
\text { slightly spreading }\end{array}$ & $\begin{array}{l}10-20(-30) \\
\text { semi-erect to drooping } \\
30-60 \mathrm{~mm} \\
\text { trumpet-shaped and curved with } \\
\text { segments open, funnel-shaped, mostly } \\
\text { spreading }\end{array}$ & $\begin{array}{l}7-10(-15) \\
\text { erect } \\
60-80 \mathrm{~mm} \\
\text { open, funnel-shaped, } \\
\pm \text { straight, segments spreading }\end{array}$ \\
\hline $\begin{array}{l}\text { Protrusion from perianth tube } \\
\text { anthers } \\
\text { stigma }\end{array}$ & $\begin{array}{l}\text { slight } \\
<7 \mathrm{~mm}\end{array}$ & $\begin{array}{l}\text { slight, variable } \\
<5 \mathrm{~mm} \text {, variable }\end{array}$ & $\begin{array}{l}\text { variable } \\
<10 \mathrm{~mm}\end{array}$ \\
\hline $\begin{array}{l}\text { Seed } \\
\text { number } \\
\text { size (diam.) } \\
\text { maturation time }\end{array}$ & $\begin{array}{l}1-4 \\
\pm 8-10 \mathrm{~mm} \\
\pm 9 \text { months }\end{array}$ & $\begin{array}{l}1-4 \\
\pm 10-15 \mathrm{~mm} \\
\pm 9 \text { months }\end{array}$ & $\begin{array}{l}1-4 \\
\pm 12-15 \mathrm{~mm} \\
\pm 12 \text { months }\end{array}$ \\
\hline Flowering time & October-December & $\begin{array}{l}\text { Erratic, mainly July-December } \\
\text { and/or February-May }\end{array}$ & October-November \\
\hline Whole distribution range & $\begin{array}{l}\text { Limpopo (Soutpansberg) Mpumalanga } \\
\text { and Swaziland }\end{array}$ & $\begin{array}{l}\text { Bearded Man Mountain, Mpumalanga } \\
\text { and Swaziland }\end{array}$ & $\begin{array}{l}\text { Eastern Cape (Transkei), KwaZulu- } \\
\text { Natal, Mpumalanga and Swaziland }\end{array}$ \\
\hline
\end{tabular}

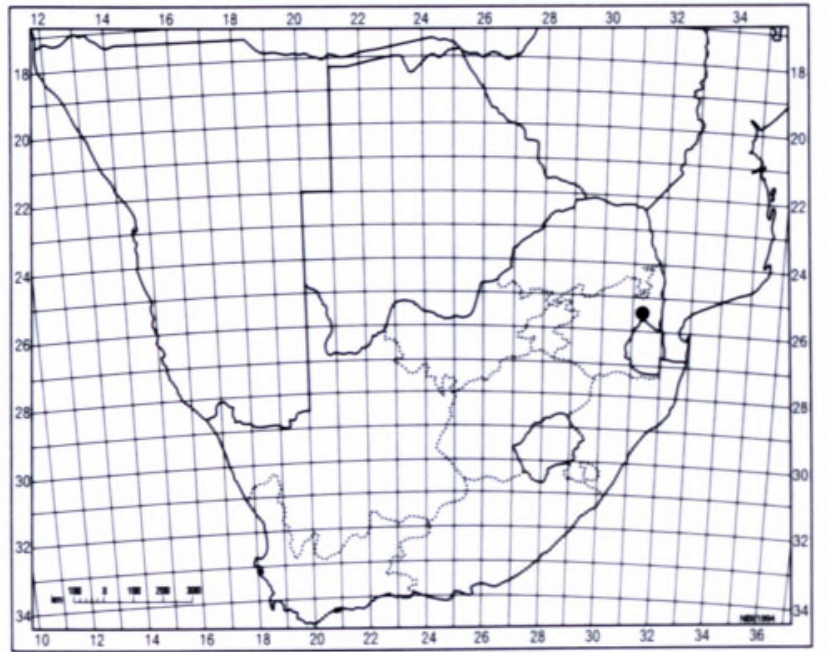

FIGURE 14.-Known geographical range of Clivia $\times$ nimbicola in nature.

refers to the mist belt habitat in which this hybrid and its putative parents are found.

\section{ACKNOWLEDGEMENTS}

Our thanks to Dr Hugh Glen for the Latin translation of the diagnosis, Ms Hester Steyn for the distribution map and Mr T.N. Pearton for the type specimen.

\section{REFERENCES}

DUNCAN, G. 1999. Grow clivias. Kirstenbosch Gardening Series. National Botanical Institute, Cape Town.

KOOPOWITZ, H. 2002. Clivia. Timber Press, Singapore

MURRAY, B.G., RAN, Y., DE LANGE, P.J., HAMMETT, K.R.W., TRUTER, J.T. \& SWANEVELDER, Z.H. 2004. A new species of Clivia (Amaryllidaceae) endemic to the Pondoland Centre of Endemism, South Africa. Botanical Journal of the Linnean Society 146: 369-374.

ROURKE, J.P. 2002. Clivia mirabilis (Amaryllidaceae: Haemantheae) a new species from Northern Cape, South Africa. Bothalia 32: $1-7$.

ROURKE, J.P. 2003. Natural interspecific hybrids in Clivia - C. miniata $\times C$. caulescens hybrids from Mpumalanga. In M. Dower. C. Felbert, J. van der Linde \& J. Winter, Clivia 5: 78-80. Clivia Society South Africa, Cape Town.

STEWART, J. \& MANNING, J.C. 1982. A new Disa hybrid in Natal. The South African Orchid Journal 13: 35-41.

SWANEVELDER, Z.H. 2003. Diversity and population structure of Clivia miniata Lindl. (Amaryllidaceae): evidence from molecular genetics and ecology. M.Sc. thesis, University of Pretoria.

VAN WYK, A.E. \& SMITH, G.F. 2001. Regions of floristic endemism in southern Africa: a review with emphasis on succulents. Umdaus Press, Pretoria.

\section{Z.H. SWANEVELDER*, J.T. TRUTER** and A.E. VAN WYK***}

* Corresponding author: Department of Botany \& Forestry and Agricultural Biotechnology Institute (FABI), University of Pretoria, 0002 Pretoria

**P.O. Box 5085, 1502 Benoni South, South Africa.

$* * *$ H.G.W.J. Schweickerdt Herbarium, Department of Botany, University of Pretoria, 0002 Pretoria.

MS. received: 2005-05-23. 